\title{
Energy Saving LED and CFL Lamps - Rated vs. True Power and Current Consumption
}

\author{
Zbigniew Mikoś, Marcin Jachimski, Andrzej Bień \\ AGH University of Science and Technology, al. Mickiewicza 30, 30-059 Krakow, Poland
}

\begin{abstract}
There is a very high availability of energy-saving lamps for consumer use on the market. Manufacturers, wanting to reach the widest possible range of customers, present on the packaging various data that do not inform the user about the real energy properties of the lamp. The authors have measured the energy parameters of several randomly selected LED and CFL lamps available in commercial networks and compared the obtained results with the parameters declared by the manufacturers.
\end{abstract}

Keywords: LED lamps, CFL lamps, power and energy measurement, power quality

\section{Introduction}

Energy-saving lamps using LED diodes as light sources (commonly referred to as LED lamp or LED light bulb) are used more and more commonly. Due to the much better lighting efficiency than the classic bulbs, they consume several or dozen times less power from the grid to produce the same luminous flux. It gives significant energy savings for individual consumers in apartments and/or houses [1] as well as for the institutional recipients in large facilities such as office buildings, shopping centers, hospitals, etc. The second beneficial feature of lighting systems based on LED luminaries is a possibility of wide lighting arrangement. This is possible due to the availability of various luminaries and the lighting control capabilities implemented in lighting systems [2].

The wide use of LED lamps causes various problems that arise in power grids resulting from the non-sinusoidal waveform of the current consumed by such lamps. For most lamps, the current waveform is qualitatively very similar, which is the result of typical solutions of power supplies used in such lamps [3]. Despite the small power and current consumed by a single lamp, problems arise from the large amount of such lamps in the same grid and their synchronous operation forced by voltage waveform in the power grid. These issues are discussed in [4-7].

Studies of LED and CFL lamps in terms of their impact on the power grid (measurements of power factor and current harmonic distortions) were carried out in various research centers and are described, for example in $[3,8]$. These studies confirm their unfavorable energy properties: harmonic distortion factor

Autor korespondujący:

Zbigniew Mikoś, mikos@agh.edu.pl

Artykuł recenzowany

nadesłany 12.11.2019 r., przyjęty do druku 05.12.2019 r. of current waveform often greater than $100 \%$ and low power factor between 0.4 and 0.95 depending on the power supply type.

On the consumer market there are a lot of energy-saving LED bulbs available from various manufacturers. Manufacturers wanting to reach the widest possible audience (mostly non-professional) often present on the packaging various data, slogans and/or illustrations (e.g. " $4 \mathrm{~W}=60 \mathrm{~W}$ "), which do not inform the user about real energy properties of the lamps. In addition, only the basic data set is given on tubes (and packages): rated supply voltage, frequency, power and current.

The authors have measured the energy parameters of several, arbitrarily selected LED lamps and two compact fluorescent lamps (CFL) available in popular commercial networks and compared the obtained measurement data with the parameters declared by the manufacturers.

\section{Energy-saving lamps tested}

A few, arbitrarily chosen energy-saving LED and CFL lamps intended for domestic use were tested. Some of these lamps were and some are widely available in stores. All tested lamps were brand new, although some of them were manufactured much formerly.

Table 1 shows the rated data of the tested LED and CFL lamps available on the lamp or its package. More detailed data have been available for lamps from one manufacturer. These data mainly focus on photometric and environmental parameters rather than electrical parameters.

For most lamps, manufacturers specified the ranges of the supply voltage $220-240 \mathrm{~V}$ and the frequency $50-60 \mathrm{~Hz}$. Only the manufacturer of lamp No. 2 (205753) specified the $230 \mathrm{~V} / 50 \mathrm{~Hz}$ supply voltage. The manufacturer of lamp No. 1 (MS-G95-1050) declared that the power factor is greater than 0.5 .

All lamps were normally used for about 3 months, 5 days per week, 2-3 hours per day. It gives that the time of use of each lamp was about 130-190 hours. Recommended time for lamp stabilization is 100 hours of continuous operation. 
Table 1. Rated data of LED and CFL lamps tested

Tabela 1. Dane znamionowe testowanych lamp LED i CFL

\begin{tabular}{|c|c|c|c|c|}
\hline No. & Type (Series) & LED/CFL & Year of prod. & Power [W] \\
\hline 1 & MS-G95-1050 & LED & 2015 & 12 \\
\hline 2 & 205753 & LED & 2016 & 12 \\
\hline 3 & LD6P & LED & 2017 & 14.5 \\
\hline 4 & Ek889 & LED & 2015 & 20 \\
\hline 5 & DuluxStar & CFL & 2009 & 23 \\
\hline 6 & Dulux & CFL & 2015 & 200 \\
\hline
\end{tabular}

\section{Test bed}

The diagram of the measurement test bed is shown in Figure 1.

The measurement system was supplied by a programmable AC voltage source Chroma 61512. The use of a stabilized voltage source made it possible to make the measurement results independent of voltage fluctuations in the power grid and provide a sinusoidal voltage with a very low harmonic distortions.

Chroma 61512 is a programmable three-phase voltage source and allows to adjust independently the voltage in each phase in the range of $0-300 \mathrm{~V}$, frequency $15-1500 \mathrm{~Hz}$ and the shift between phases from $0^{\circ}$ to $360^{\circ}$. The maximum output power of the source is $18 \mathrm{~kW}(3 \quad 6 \mathrm{~kW})$, and the total harmonic distortions of voltages are maximum $0.3 \%$ at $50 \mathrm{~Hz}, 1 \%$ in the frequency range from $15 \mathrm{~Hz}$ to $1 \mathrm{kHz}$ and $1.5 \%$ at above $1 \mathrm{kHz}$.

The RIGOL DS1074 digital storage oscilloscope was used to observe and store voltage and current waveforms. The sampling frequency was $50 \mathrm{kHz}$, which gives 1000 samples per 1 voltage period of the grid. The resolution of the A/D converters in the oscilloscope is 8 bits. Total accuracy of the oscilloscope vertical channel (input amplifier and A/D converter) is $\pm 3 \%$ of full range.

The voltage signal was measured across the output of the voltage divider consisting of $\mathrm{R} 1$ and $\mathrm{R} 2$. On the basis of the measurements, a voltage divider ratio of 270:1 was determined. The current signal was obtained from non-inductive shunt resistor Rs of $0.62 \Omega$ resistance.

The voltage and current waveforms were saved in csv format files.

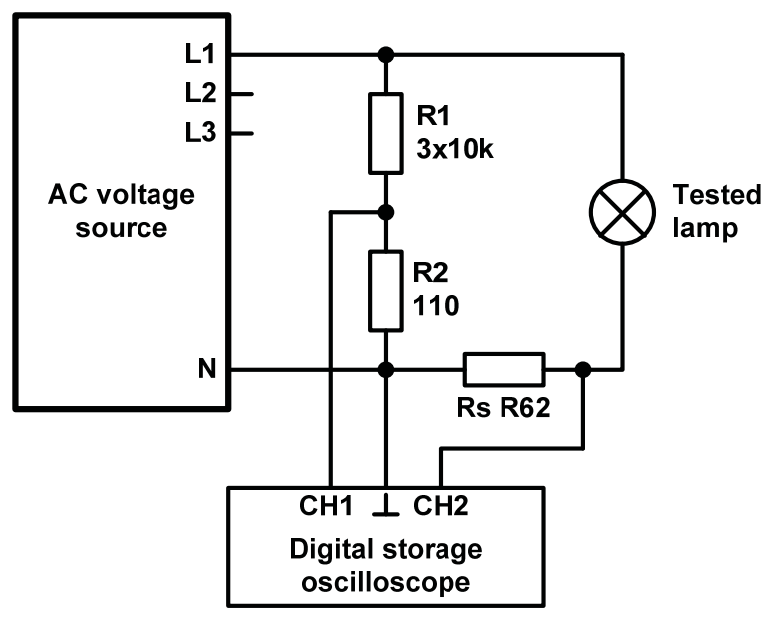

Fig. 1. The measurement test bed diagram

Rys. 1. Schemat blokowy stanowiska testowego

\section{The method of the results elaboration}

In order to average the results, the calculation was made on the basis of data collected for $100 \mathrm{~ms}$, that is 5 periods of mains voltage. The integration time of $100 \mathrm{~ms}$ is not in accordance with the guidelines of the EN 61000-4-30 standard. Recommended integration time is $200 \mathrm{~ms}$ for class A instruments. The choice of the non-standard integration time was due to the memory limitation of oscilloscope used.

Active and apparent power, voltage and current RMS (root mean square) values were calculated according to their physical definitions.

On the basis of voltage and current samples, the power consumed by the lamp was calculated according to (1).

$$
p_{k}=u_{k} \cdot i_{k}
$$

where: $u_{k}, i_{k}, p_{k}-k$-sample of voltage, current and power.

Active power $P$ was calculated as the average of instantaneous power values according to (2). The rectangles method was used for numerical integration.

$$
P=\frac{1}{t_{n}-t_{0}} \sum_{k=0}^{n-1} p_{k}\left(t_{k+1}-t_{k}\right)
$$

where: $p_{k}-k$-sample of instantaneous power, $t_{k}$ - time of $k$-sample, $n$ - number of samples. In the calculations $n$ was 5000 .

The RMS values of voltage $U$ and current $I$ were calculated based on the voltage $u_{k}$ and current $i_{k}$ samples according to the expressions (3) and (4).

$$
\begin{gathered}
U=\sqrt{\frac{1}{t_{n}-t_{0}} \sum_{k=0}^{n-1} u_{k}^{2}\left(t_{k+1}-t_{k}\right)} \\
I=\sqrt{\frac{1}{t_{n}-t_{0}} \sum_{k=0}^{n-1} i_{k}^{2}\left(t_{k+1}-t_{k}\right)}
\end{gathered}
$$

where: $u_{k}, i_{k}-k$-sample of voltage and current, $t_{k}-$ time of $k$-sample, $n$ - number of samples. In the calculations $n$ was 5000 . 
Apparent power $S$ was calculated according to expression (5) as a product of RMS voltage and RMS current values.

$$
S=U \cdot I
$$

where: $U$ - RMS value of voltage, $I-$ RMS value of current.

The power factor $P F$ and the current crest factor $C F$ were calculated in accordance with their definitions (6) and (7).

$$
\begin{gathered}
P F=\frac{P}{S} \\
C F=\frac{\left|I_{\max }\right|}{I}
\end{gathered}
$$

where: $P, S$ - active and apparent power, $I_{\max }, I-$ peak and RMS current values.

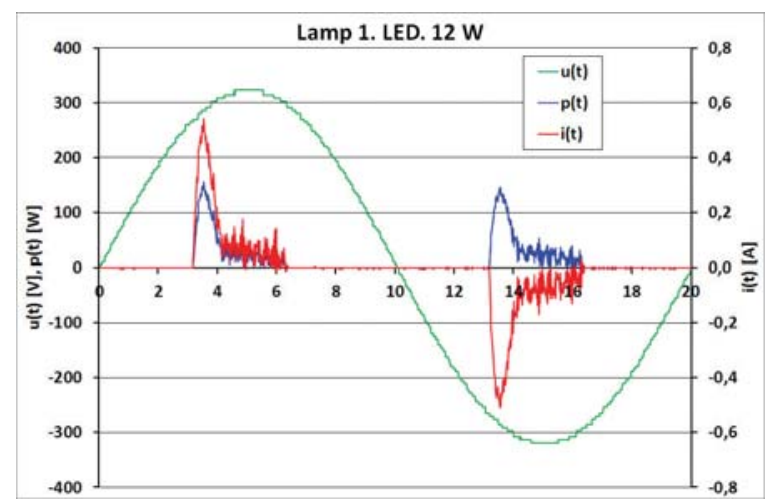

(a)

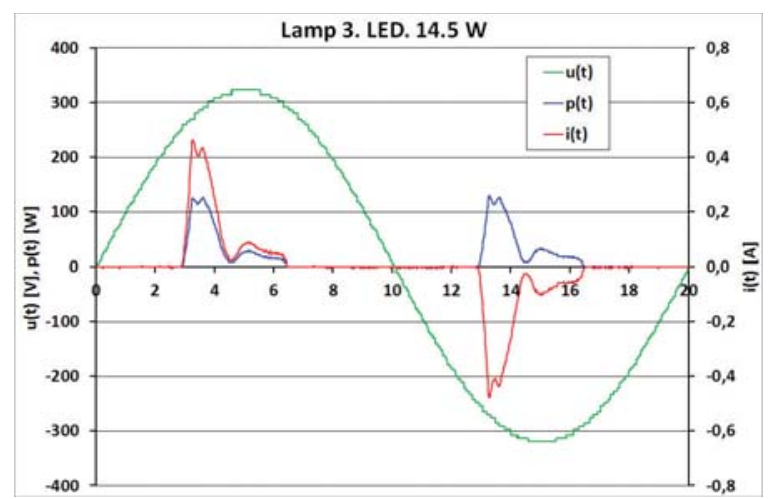

(c)

\section{The measurement results}

Figures 2 and 3 show the voltage, current and power waveforms of the tested lamps during one period of the mains voltage. All charts have the same scales on both axes. However, you should not directly compare the waveforms between each other, because the power of each bulb is different.

The grain of the voltage waveform results from the 8-bit sampling of the oscilloscope used for waveform recording.

Current waveforms indicate that the majority of LED and CFL lamps have a rectifier bridge with voltage ripple filtering capacitor at the power input (type A according to [3]). This is indicated by the initial current peak characteristic of such a power supply system. This hypothesis is confirmed by the analysis of available lamp supply circuit schemes. Probably a different power supply is used in lamp No. 4 (Ek889), in which the supply current has almost a constant value at the beginning of each half-period of the supply voltage for about $3 \mathrm{~ms}$.

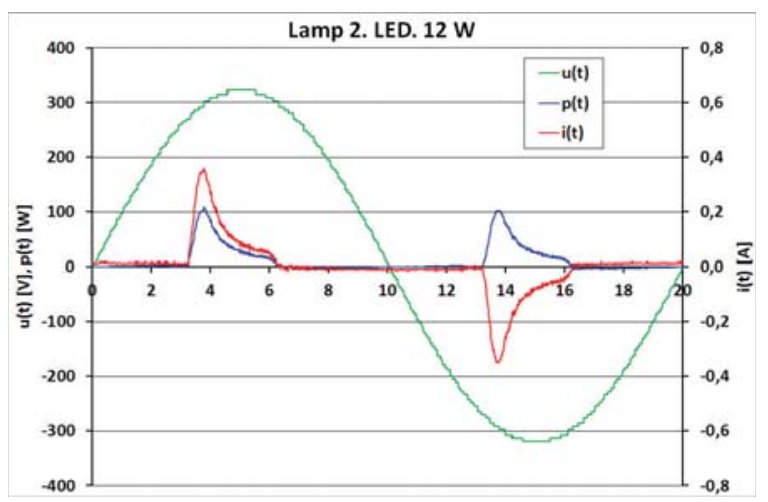

(b)

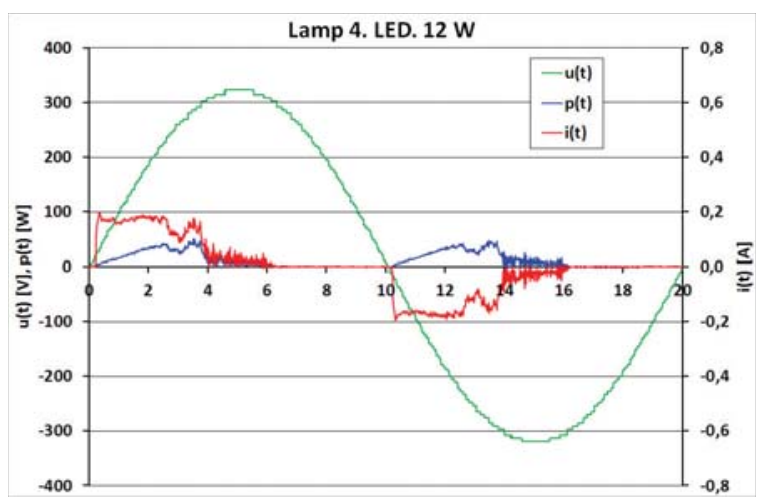

(d)

Fig. 2. Voltage $(\mathrm{u}(\mathrm{t}))$, current $(\mathrm{i}(\mathrm{t}))$ and power $(\mathrm{p}(\mathrm{t}))$ waveforms of LED lamps: (a) Lamp No. 1, (b) Lamp No. 2, (c) Lamp No. 3, (d) Lamp No. 4 Rys. 2. Przebiegi napięcia $(\mathrm{u}(\mathrm{t}))$, prądu $(\mathrm{i}(\mathrm{t}))$ i mocy $(\mathrm{p}(\mathrm{t}))$ dla lamp LED: (a) lampa nr 1, (b) lampa nr 2, (c) lampa nr 3, (d) lampa nr 4

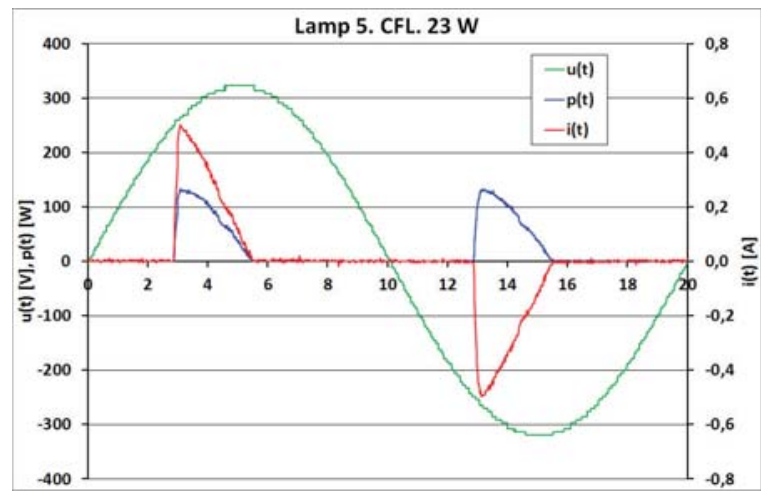

(a)

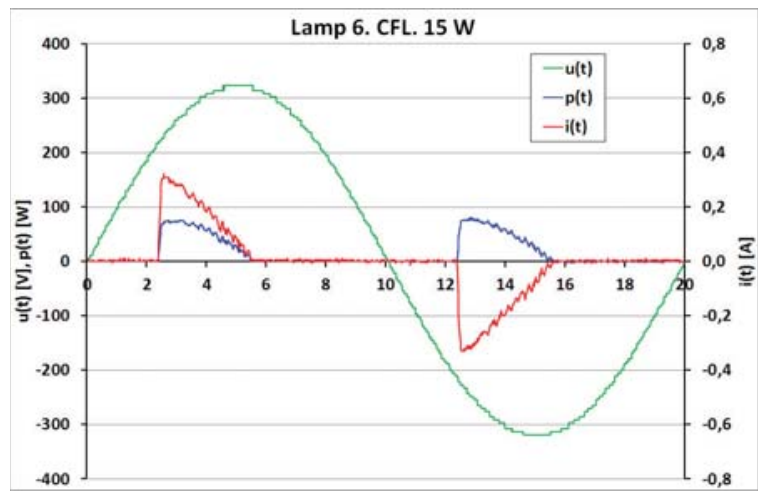

(b)

Fig. 3. Voltage $(u(t))$, current $(i(t))$ and power $(p(t))$ waveforms of CFL lamps: (a) Lamp No. 5, (b) Lamp No. 6

Rys. 3. Przebiegi napięcia $(u(t))$, prądu $(i(t))$ i mocy $(p(t))$ dla lamp CFL: (a) lampa $n r 5$, (b) lampa nr 6 
Table 2. Energy parameters of lamps - measurement results

Tabela 2. Parametry energetyczne lamp - wyniki pomiarów

\begin{tabular}{|c|c|c|c|c|c|c|c|c|}
\hline No. & Type & $\begin{array}{c}\text { RMS voltage } \\
\mathrm{U}[\mathrm{V}]\end{array}$ & $\begin{array}{l}\text { RMS current } \\
\quad \text { I }[\mathrm{mA}]\end{array}$ & $\begin{array}{l}\text { Peak current } \\
\operatorname{Imax}[\mathbf{A}]\end{array}$ & $\begin{array}{l}\text { Active power } \\
\qquad \mathbf{P}[\mathbf{W}]\end{array}$ & $\begin{array}{c}\text { Apparent power } \\
\text { S [VA] }\end{array}$ & $\begin{array}{c}\text { Power factor } \\
\text { PF [-] }\end{array}$ & $\begin{array}{c}\text { Crest factor } \\
\text { CF [-] }\end{array}$ \\
\hline 1 & LED & 227.3 & 113 & 542 & 13.16 & 25.64 & 0.513 & 4.81 \\
\hline 2 & LED & 227.3 & 92 & 360 & 12.32 & 20.95 & 0.588 & 3.90 \\
\hline 3 & LED & 227.3 & 123 & 503 & 15.81 & 28.03 & 0.564 & 4.08 \\
\hline 4 & LED & 227.3 & 96 & 197 & 11.51 & 21.93 & 0.525 & 2.04 \\
\hline 5 & $\mathrm{CFL}$ & 227.3 & 159 & 503 & 21.06 & 36.21 & 0.582 & 3.16 \\
\hline 6 & $\mathrm{CFL}$ & 227.3 & 114 & 335 & 15.93 & 26.02 & 0.612 & 2.93 \\
\hline
\end{tabular}

Such a current waveform is difficult to classify to any of the types of supply systems described in [3].

Table 2 presents the results of measurements of the actual energy parameters of lamps: RMS and peak value of current, active and apparent power, power factor and crest factor. These results were obtained on the basis of equations (2)-(7). For all measurements, the RMS voltage value according to (3) was $227.3 \mathrm{~V}$.

The measured electrical parameters of the lamps that are collected in Table 2 reflect the large deformation of the current consumed by the energy-saving lamps shown in Figures 2 and 3. All lamps have a low power factor ranging from 0.513 to 0.612 and a high current crest factor: from 2.04 to 4.81 . One can also notice large differences in the crest factor of individual lamps, despite the small differences between power factors (standard deviation is 0.035 for an average of 0.565 ). This is due to differences in the circuit design of the lamps supply systems that cause a different distribution of harmonics of the supply current.

Tables 3 and 4 present the comparisons of rated and measured parameters of the lamps: active power and RMS current. The relative difference is calculated in relation to the rated value.

The results presented in Table 3 show that the active power declared by producers differs from the measured by not more than $\pm 10 \%$. The average of absolute values of relative difference is $6.8 \%$, the standard deviation $-2.8 \%$ and the maximum difference $-9.6 \%$. This differences allow to assume that the nominal power of the lamp given by the manufacturer reflects the actual active power consumption taking into account the scatter of the parameters of the electronic components used for the production of lamps.

Much bigger differences occur between declared and actual current (Table 4). The average of absolute values of differences is $23.6 \%$, the standard deviation is $17.3 \%$, and the maximum difference is $50.7 \%$. Based on the available data, it is difficult to indicate the reason for such differences. One of the possible reasons is the use of various current measurement methods by manufacturers. Due to the high distortion of the current waveform form a sinusoid, simplified methods based on the measurement of average rectified and/or maximum value give erroneous results. The correct results can be obtained using a measurement based on the definition of the RMS value (True RMS).

\section{Lighting energy efficiency improvement}

Impact of energy-saving lamps on power reduction is obvious. Energy-saving lamps take less power vs. traditional incandescent bulbs offering the same luminous flux. But there is one more hidden advantage. Also losses of the power line caused by current flow are reduced because the current is reduced.

The authors have made some calculations to estimate the effect of reduction of power losses of the grid.

Table 3. Comparison of rated and actual power of lamp

Tabela 3. Porównanie znamionowej i rzeczywistej mocy lamp

\begin{tabular}{|c|c|c|c|c|}
\hline No. & Type & $\begin{array}{c}\text { Rated power } \\
{[\mathbf{W}]}\end{array}$ & $\begin{array}{c}\text { Actual power } \\
{[\mathbf{W}]}\end{array}$ & $\begin{array}{c}\text { Relative difference } \\
{[\%]}\end{array}$ \\
\hline 1 & LED & 12 & 13.16 & 9.6 \\
\hline 2 & LED & 12 & 12.32 & 2.7 \\
\hline 3 & LED & 14.5 & 15.81 & 9.0 \\
\hline 4 & LED & 12 & 11.51 & -4.1 \\
\hline 5 & CFL & 23 & 21.06 & -8.4 \\
\hline 6 & CFL & 15 & 15.93 & 6.2 \\
\hline
\end{tabular}


Table 4. Comparison of rated and actual RMS current of lamps

Tabela 4. Porównanie znamionowej i rzeczywistej wartości skutecznej prądu lamp

\begin{tabular}{|c|c|c|c|c|}
\hline No. & Type & $\begin{array}{c}\text { Rated current } \\
{[\mathbf{m A}]}\end{array}$ & $\begin{array}{c}\text { Actual current } \\
{[\mathbf{m A}]}\end{array}$ & $\begin{array}{c}\text { Relative difference } \\
{[\%]}\end{array}$ \\
\hline 1 & LED & 90 & 92 & -38.6 \\
\hline 2 & LED & 150 & 13.3 & 2.8 \\
\hline 3 & LED & 120 & 96 & -20.4 \\
\hline 4 & LED & 64 & 159 & -23.7 \\
\hline 5 & CFL & 200 & 114 & 50.7 \\
\hline
\end{tabular}

Table 5 presents the selected rated data of the studied energy lamps and incandescent lamps that produce a similar rated luminous flux. The reference incandescent lamps were chosen from standard $230 \mathrm{~V}$ bulbs with E27 mounting manufactured by Osram. The rated luminous flux of these incandescent lamps differs no more than $\pm 10 \%$ from the luminous flux of the corresponding energy-saving lamps.
Table 6 presents the change in energy consumption and change in energy losses in the power grid.

Column 3 of Table 6 shows the relative reduction in energy consumption (saving) for each energy-saving lamp in relation to the incandescent light source assuming the same exposure time. The reduction in energy consumption was calculated according to (8).

Table 5. LED and CFL lamps and their incandescent equivalent

Tabela 5. Lampy LED i CFL i ich odpowiedniki żarowe

\begin{tabular}{|c|c|c|c|c|c|}
\hline \multirow{2}{*}{ No. } & \multicolumn{3}{|c|}{ LED or CFL lamp } & \multicolumn{2}{c|}{ Incandescent lamp } \\
\cline { 2 - 6 } & Type & $\begin{array}{c}\text { Rated power } \\
{[\mathbf{W}]}\end{array}$ & $\begin{array}{c}\text { Luminous flux } \\
{[\mathrm{lm}]}\end{array}$ & $\begin{array}{c}\text { Rated power } \\
{[\mathbf{W}]}\end{array}$ & $\begin{array}{c}\text { Current } \\
{[\mathbf{A}]}\end{array}$ \\
\hline 1 & LED & 12 & 1050 & 75 & 0.33 \\
\hline 2 & LED & 12 & 1050 & 75 & 0.33 \\
\hline 3 & LED & 14.5 & 1520 & 100 & 0.43 \\
\hline 4 & LED & 12 & 1100 & 75 & 0.33 \\
\hline 5 & CFL & 23 & 1600 & 100 & 0.43 \\
\hline 6 & CFL & 15 & 900 & 60 & 0.26 \\
\hline
\end{tabular}

Table 6. Changes in energy consumption and energy losses

Tabela 6. Zmiany zużycia energii i start energii w sieci

\begin{tabular}{|c|c|c|c|c|c|}
\hline \multirow{2}{*}{ No. } & \multirow{2}{*}{ Type } & \multirow{2}{*}{$\begin{array}{c}\text { Relative } \\
\text { reduction } \\
\text { of energy } \\
\text { consumption } \\
{[\%]}\end{array}$} & \multicolumn{3}{|c|}{ Relative changes in energy losses in grid for ... [\%] } \\
\hline & & & real $\mathrm{PF}$ & $\mathrm{PF}=1.0$ & $\mathrm{PF}=0.95$ \\
\hline 1 & 2 & 3 & 4 & 5 & 6 \\
\hline 1 & LED & 84.0 & -88.0 & -96.8 & -96.5 \\
\hline 2 & LED & 84.0 & -92.0 & -97.2 & -96.9 \\
\hline 3 & LED & 85.5 & -92.0 & -97.4 & -97.2 \\
\hline 4 & LED & 84.0 & -91.2 & -97.6 & -97.3 \\
\hline 5 & CFL & 77.0 & -86.6 & -95.5 & -95.0 \\
\hline 6 & CFL & 75.0 & -80.7 & -92.8 & -92.0 \\
\hline
\end{tabular}




$$
\Delta E=\frac{P_{n I L}-P_{n E S L}}{P_{n I L}} \cdot 100
$$

where: $\Delta E$ - relative reduction of energy consumption, $P_{n E S L}$ - rated power of an energy-saving lamp, $P_{n I L}$ - rated power of an equivalent incandescent lamp.

Columns 4 and 5 of Table 6 show the relative change in losses of power dissipated on the resistance of the power line caused by the energy-saving lamp current flow (related to an equivalent incandescent source). Data in column 4 show the change of energy losses ( $\triangle \mathrm{EL} 1)$ caused by the flow of real, distorted current, and in columns 5 and 6 the change of losses ( $\triangle \mathrm{EL} 2)$ that would be generated by the energy-saving lamp if the power factor of the lamp was 1.0 and 0.95 . Values in columns 4, 5 and 6 were calculated in accordance with (9), (10) and (11).

$$
\begin{gathered}
\Delta E_{L 1}=\frac{I_{E S L}^{2}-I_{I L}^{2}}{I_{I L}^{2}} \cdot 100 \\
\Delta E_{L 2}=\frac{I_{E S L 100}^{2}-I_{I L}^{2}}{I_{I L}^{2}} \cdot 100 \\
\Delta E_{L 3}=\frac{I_{E S L 095}^{2}-I_{I L}^{2}}{I_{I L}^{2}} \cdot 100
\end{gathered}
$$

where: $\Delta_{E L 1}$ - relative change of power losses in the power line caused by the actual lamp current, $\Delta_{E L 2}, \Delta_{E L S}$ - relative change of power losses in the power line caused by the current of the lamp with power factor 1.0 and $0.95, I_{E S L}$ - real RMS current of the energy-saving lamp, $I_{E S L 100}, I_{E S L 095}-$ RMS current of the energy-saving lamp with a power factor 1.0 and $0.95, I_{I L}-\mathrm{RMS}$ current of an equivalent incandescent lamp

The reduction of energy consumption results directly from the much better efficiency of LED and CFL energy-saving lamps. For LED and CFL lamps it is $60-100 \mathrm{~lm} / \mathrm{W}$, and for incandescent lamps - 10-15 lm/W.

The results in column 4 of Table 6 also show significant reduction in losses of power dissipated on the resistance of the power line. Losses on the resistance of the power line depend on the square of the RMS value of the current, which is several times less than the current of the equivalent incandescent lamp.

The values in column 5 show the limit to which the losses in the power line can be reduced (if the power supply of the energy-saving lamps consumes the sinusoidal current in phase with the supply voltage, i.e. the lamp power factor equals to 1.0). These values have rather theoretical meanings. To reach the power factor of 1.0 it is necessary to use sophisticated and complex power supplies for the lamps. That would not be economically viable. Differences in values in columns 4 and 5 inform about power losses caused by the higher harmonics of the lamp current.

The values in column 6 present the reduction of the power line loses if the lamp power factor is 0.95 . Thanks to many and low cost integrated circuits to control power supplies with power factor correction, it is much easier to construct the power supply with power factor in range $0.9-0.95$ than with 1.0. This solution is more economically justified although the price of the lamp will probably be higher. Comparing the values in columns 5 and 6 you can see that the reduction of the loses in power line is practically the same for power factor of 1.0 and 0.95 .

\section{Discussion and conclusions}

Despite a small sample of energy-saving lamps tested, the high similarity of the results of measurements of individual lamps allow to draw some more general conclusions.

The power of lamps declared by the manufacturer correspond to the active power consumed from the grid with a relative difference not exceeding $\pm 10 \%$. This result can be considered satisfactory. Most lamps (4 out of six) consumed more than declared power. Such a result is difficult to classify as positive or negative, because no measurements of the luminous flux were made to determine whether the higher power absorbed from the grid gives a greater flux of light than declared by the manufacturer.

The actual current consumed by 5 lamps (out of six) showed a value different than the declared value of more than $\pm 20 \%$. The biggest difference was 50\%. Some producers (lamps 2, 6 and 7) declare a current greater than the actual measured current. The difference is from $20 \%$ to $50 \%$ relative to the rated current of the lamps. In one case (lamp 5), the manufacturer's data can be considered unreliable. A simple calculation shows that the power factor of this lamp would have to be over 0.8. The lamp of such power factor value requires to use the supply system with a power factor correction.

The power factor of the lamps is low and ranges from 0.5 to 0.65 , and the current crest factor is from 2.0 to 4.8 . These values indicate a very big distortions of the current waveform from a sinusoid, which is visible in Fig. 2-8. The values of power factor and crest factor indicate the adverse impact of lamps on the power grid. Despite the small power of the single load, the large number of installed lamps and their synchronous operation forced by line voltage waveform can cause a low power factor of building power network in which such lighting is used.

By analyzing qualitatively voltage and current waveforms of lamps (Fig. 2, 3), one can notice that the shape and position of the current waveform in relation to the voltage waveform are very similar for all lamps. This causes the lamp currents in large lighting installations are added "almost" algebraically. As a result, the power factor of the entire installation approximately equals to the power factor of individual lamps. On the other hand, it can be seen that the first harmonic of the current is shifted relative to the voltage waveform by a negative angle, so it is "ahead of" the voltage. The installation of more lamps may reduce the inductive reactive power consumption generated by the first harmonic current. The conclusions presented in this paragraph are based on qualitative observation of waveforms and require quantitative confirmation.

Using the energy-saving LED and/or CFL light sources significantly increase the energy efficiency of lighting in relation to incandescent lighting. This is due to the following reasons:

- several times smaller (5-8 times) power of energy-saving lamps needed to obtain the required luminous flux compared to the power of incandescent lamps. For the compared lamps this gives a reduction in energy consumption in the range of $70-85 \%$.

- significant reduction of losses in the power grid caused by the flow of the lamp supplying current. For the tested lamps, these losses decrease by $80-92 \%$ in relation to the losses caused by the flow of current to the equivalent incandescent lamps.

Further reduction of losses in the power grid (by about 10\%) is possible under the condition of using the lamps with power supplies with a power factor of 1.0. The energy-saving lamps would then take a sinusoidal current in the phase with the supply voltage. Two ways of further losses reduction can be considered: - the use of lamps equipped with power supplies with a power factor close to 1.0. The reasonable value of the power factor seems to be $0.9-0.95$. Comparing the reduction of the loses in power line by the lamps with the power factor equals to 1.0 
and 0.95 (Table 6 columns 5,6) you will notice a very little reduction of loses with the power factor rising from 0.95 to 1.0. The lamps the power factor better than 0.9 are currently not widely available. Most likely the price of lamp with such power supplies will be higher than the prices of lamps with standard power supplies.

- the use of local harmonic filters for the lamp group so that the higher harmonic current components do not flow across the entire network.

The use of energy-saving LED or CFL type lamps brings high energy benefits as a result of a significant reduction in energy consumption. The main disadvantage of today's LED and CFL lamps is a very non-linear current consumption that cause disturbances in the grid an additional energy loses. It can be improved by using better power supplies in this kind of lamps by the manufacturers.

\section{References}

1. Zeb A., de Andrade Romero M., Baiguskarov D., Aitbayev S., Strelets K., LED Lightbulbs as a Source of Electricity Saving in Buildings, "MATEC Web of Conferences", Vol. 73, 2016, DOI: 10.1051/matecconf/20167302004.

2. Wiśniewski A., Oprawy oświetleniowe LED z możliwościa regulacji mocy, „Przegląd Elektrotechniczny”, Vol. 94, No. 7, 2018, 196-199, DOI: 10.15199/48.2018.07.48.

3. Xu X., Collin A., Djokic S.Z., Langella R., Testa A., Drapela J., Experimental Evaluation and Classification of LED Lamps for Typical Residential Applications, 2017 IEEE PES Innovative Smart Grid Technologies Conference Europe (ISGT-Europe), Torino, Italy. DOI: 10.1109/ISGTEurope.2017.8260292.

4. Natthanon P., Chaiyan J., Atthapol N., Harmonics and Reduction of Energy Consumption in Lighting Systems by Using LED Lamps, "Energies", Vol. 11, No. 11, 2018, DOI: $10.3390 /$ en11113169.

5. Adoghe A.U., Eberechukwu O.C., Sanni T.F., The Effect of low power factor Led Lamp Invasion on the Utility Grid: A Case Study of Nigerian Market, 2017 IEEE PES PowerAfrica, 27-30 June 2017, Accra, Ghana.

DOI: 10.1109/PowerAfrica.2017.7991260.

6. Bunjongjit S., Ngaopitakkul A., Leelajindakrairerk M., Analysis of harmonics in indoor Lighting System with LED and fluorescent luminaire, 2017 IEEE 3rd International Future Energy Electronics Conference and ECCE Asia, 3-7 June 2017, Kaohsiung, Taiwan.
DOI: 10.1109/IFEEC.2017.7992380.

7. Galla S., Włas M., Wpływ systemów oświetleniowych LED na zaburzenia nisko częstotliwościowe, „Przegląd Elektrotechniczny", Vol. 95, No. 3, 2019, 29-32, DOI: $10.15199 / 48.2019 .03 .07$.

8. Oliveira G.D., de Oliveira E.P., da Silva A.P., Carvalho C.C.M.D., Power Quality of LED Lamps, $201617^{\text {th }}$ International Conference on Harmonics and Quality of Power (ICHQP), 16-19 Oct. 2016, Belo Horizonte, Brazil. DOI: 10.1109/ICHQP.2016.7783359.

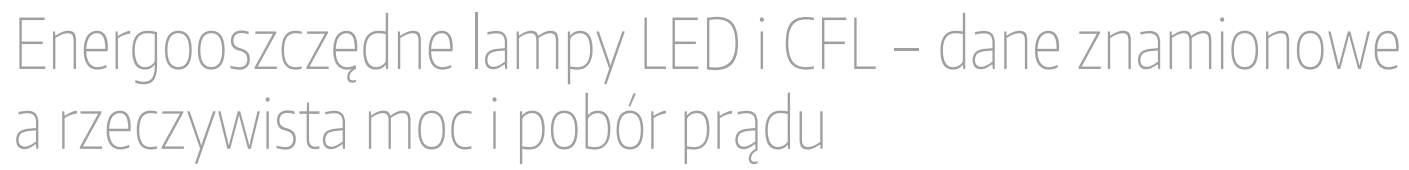

\author{
Streszczenie: Na rynku można zauważyć bardzo dużą dostępność lamp energooszczędnych \\ przeznaczonych do zastosowań konsumenckich. Producenci, chcąc dotrzeć do jak najszerszego \\ kręgu odbiorców, prezentują na opakowaniach różne dane, które nie informują użytkownika \\ o rzeczywistych własnościach energetycznych lampy. Autorzy wykonali pomiary parametrów \\ energetycznych kilku, przypadkowo wybranych lamp LED oraz CFL dostępnych w sieciach \\ handlowych i porównali otrzymane dane pomiarowe z parametrami deklarowanymi przez \\ producentów.
}




\section{Zbigniew Mikoś, PhD}

mikos@agh.edu.p ORCID: 0000-0001-9962-4726

He received the MSc degree in electrical engineering in 1984 and the PhD degree in 1999 from the Faculty of Electrical Engineering, Automatics and Electronics of AGH University of Science and Technology in Krakow. He has been working at the ACH University of Science and Technology since 1984, currently as an assistant professor at the Department of Power Electronics

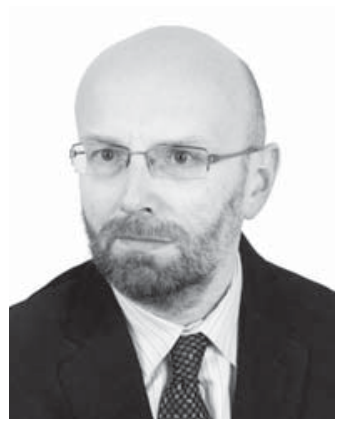
and Energy Control Systems. His current interest includes power electronics, programmable control systems in industry and embedded systems. He has many industrial solutions in his professional career, among others the control system of the synchronous motor fed by the cycloconverter, control systems of synchronous motors excitation and software development for control and regulation systems based on PLC/PAC in various industries.

\section{Marcin Jachimski, PhD \\ jachim@agh.edu.pl \\ ORCID: 0000-0002-5787-5671}

He graduated from the Faculty of Electrical Engineering, Automatics and Electronics of AGH University of Science and Technology in Krakow in 1988 - specialty automation and metrology. He obtained his doctoral degree in 2004 presenting his thesis entitled "Selected issues of the design and application of programmable

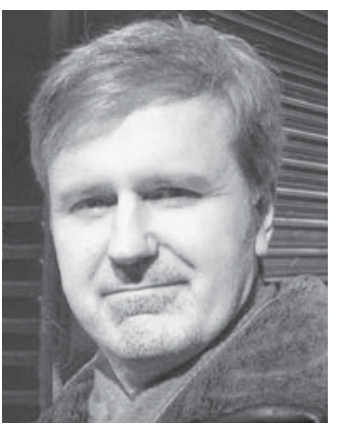
controllers". He has worked at AGH since

1988, currently as an adjunct at the Department of Power Electronics and Energy Control Systems. He deals with the issues of programmable control systems for the industry and building automation, including mainly hardware and programming languages for industrial PLC/PAC controllers. He has a number of scientific publications, proprietary solutions and industrial implementations.

\section{Prof. Andrzej Bień, PhD, DSc}

abien@agh.edu.p

ORCID: 0000-0001-9409-2169

Professor Andrzej Bień graduated with honors from the Faculty of Electrical Engineering, Automatics and Electronics of AGH University of Science and Technology in Cracow in 1979. His career is all the time associated with this faculty. Currently he works as a professor leading classes with students of electrical metrology and rese-

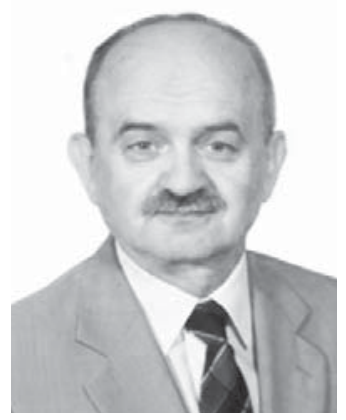
arch related to electricity supply. The main professional interests are the instrumentation and the measurement systems that use the latest digital technologies, in particular research problems concerning the measurement of electricity quality parameters. He published more than 160 scientific papers and two monographs. He is the author of 8 patents in the area of the electrical measurements. He is a member of a few professional organizations: SEP, PTETiS and IEEE. She participates in the Polish Committee for Standardization, Technical Committee 304. He practices active tourism and winter skiing. 